Prepared in cooperation with the Tennessee Valley Authority

\title{
Effects of Ground water Withdrawals Associated with Combined-Cycle Combustion Turbine Plants in West Tennessee and Northern Mississippi
}

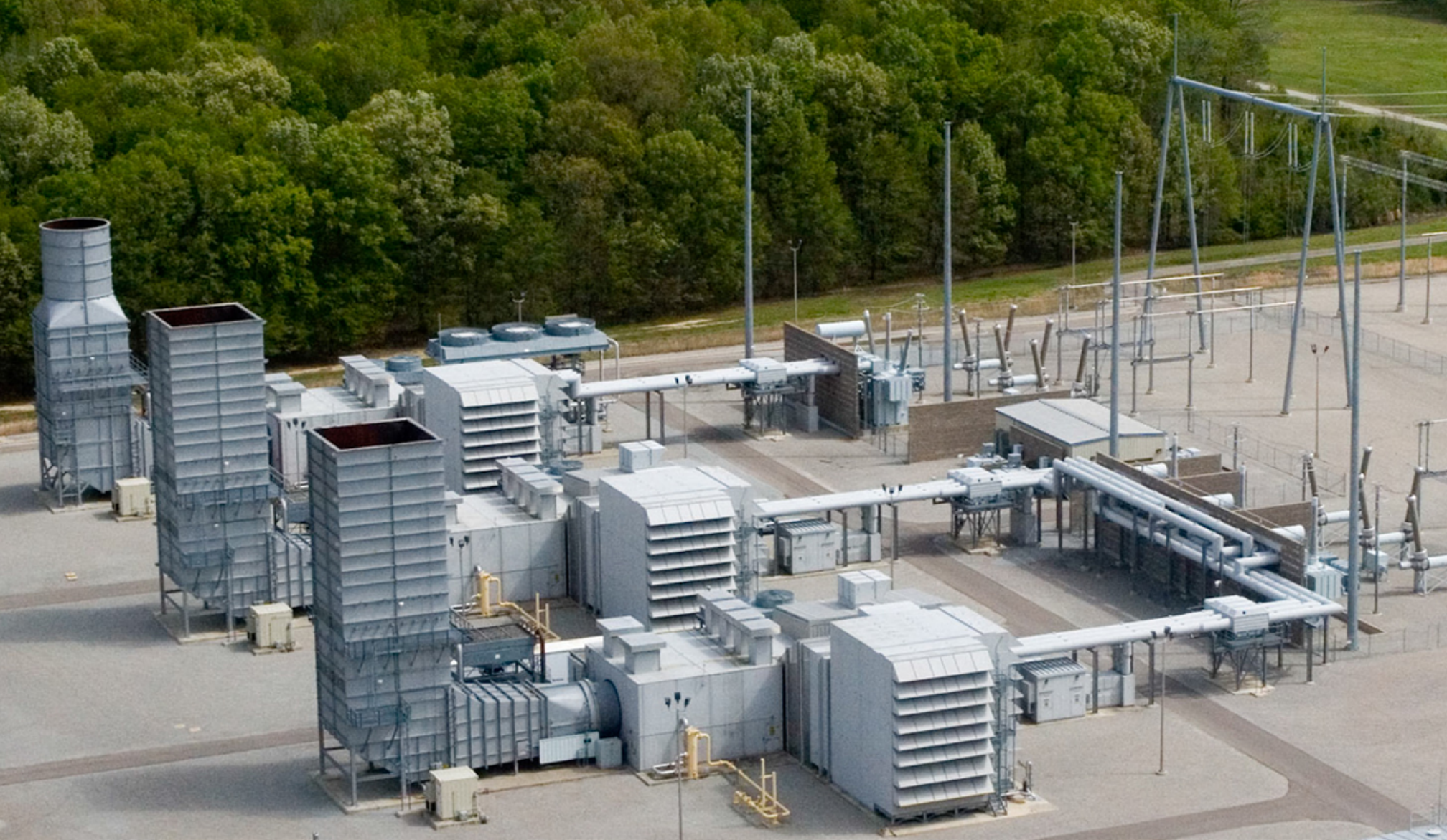

Scientific Investigations Report 2012-5072 
Photographs. Front cover: Gleason combustion turbine plant, Weakley County, Tennessee; title page: Southaven combined-cycle plant, Desoto County, Mississippi. Photographs courtesy of Tennessee Valley Authority. 


\title{
Effects of Groundwater Withdrawals Associated with Combined-Cycle Combustion Turbine Plants in West Tennessee and Northern Mississippi
}

\author{
By Connor J. Haugh
}

Prepared in cooperation with the Tennesse Valley Authority

Scientific Investigations Report 2012-5072 


\title{
U.S. Department of the Interior \\ KEN SALAZAR, Secretary \\ U.S. Geological Survey \\ Marcia K. McNutt, Director
}

\section{U.S. Geological Survey, Reston, Virginia: 2012}

\author{
For more information on the USGS — the Federal source for science about the Earth, its natural and living resources, \\ natural hazards, and the environment, visit http://www.usgs.gov or call 1-888-ASK-USGS \\ For an overview of USGS information products, including maps, imagery, and publications, \\ visit http://www.usgs.gov/pubprod \\ To order this and other USGS information products, visit http://store.usgs.gov
}

Any use of trade, product, or firm names is for descriptive purposes only and does not imply endorsement by the U.S. Government.

Although this report is in the public domain, permission must be secured from the individual copyright owners to reproduce any copyrighted materials contained within this report.

Suggested citation:

Haugh, C.J., 2012, Effects of groundwater withdrawals associated with combined-cycle combustion turbine plants in west Tennessee and northern Mississippi: U.S. Geological Survey Scientific Investigations Report 2012-5072, 22 p. 


\section{Contents}

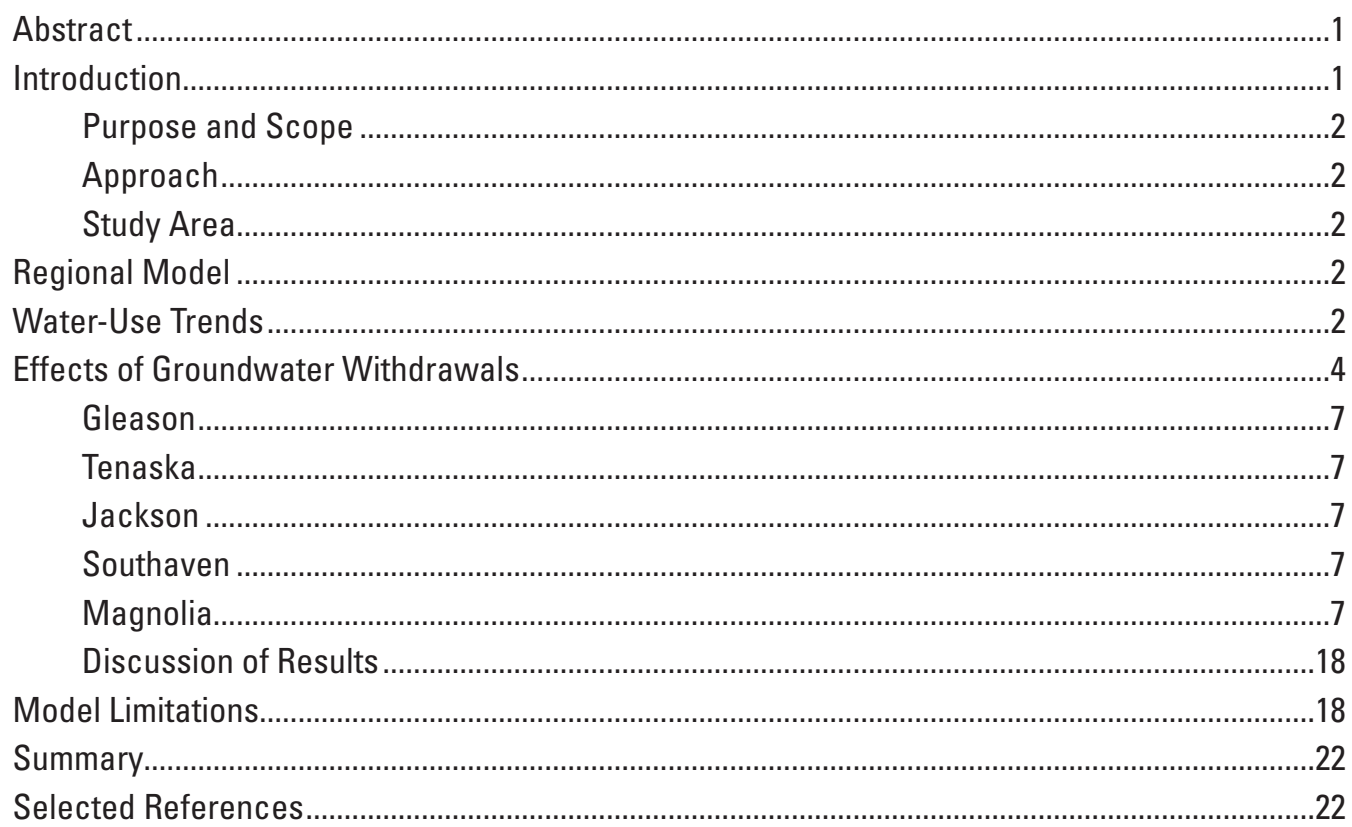

\section{Figures}

Maps showing-

1. Locations of potential combined-cycle turbine plants in Tennessee and Mississippi.

2. Simulated potentiometric surface change in the Memphis/Sparta aquifer from combined-cycle-plant withdrawals at proposed combined-cycle turbine plants

3. Simulated potentiometric surface change in the Lower Wilcox/Fort Pillow aquifer from combined-cycle-plant withdrawals at proposed combined-cycle turbine plants

4. Local grid refinement area at the Gleason site, Weakley County, Tennessee ...........8

5. Simulated potentiometric surface change in the Memphis aquifer from combined-cycle-plant withdrawals at the Gleason site, Weakley County, Tennessee ..

6. Simulated potentiometric surface change in the Fort Pillow aquifer from combined-cycle-plant withdrawals at the Gleason site,

Weakley County, Tennessee.

7. Local grid refinement area at the Tenaska site, Haywood County, Tennessee ........11

8. Simulated potentiometric surface change in the Memphis aquifer from combined-cycle-plant withdrawals at the Tenaska site, Haywood County, Tennessee .

9. Simulated potentiometric surface change in the Memphis aquifer from combined-cycle-plant withdrawals at the Jackson site, Madison County, Tennessee .

10. Simulated potentiometric surface change in the Fort Pillow aquifer from combined-cycle-plant withdrawals at the Jackson site, Madison County, Tennessee . 


\section{Figures-Continued}

Maps showing-

11. Simulated potentiometric surface change in the Lower Wilcox/Fort Pillow aquifer from combined-cycle-plant withdrawals at the Southaven site, DeSoto County, Mississippi

12. Simulated potentiometric surface change in the Upper Wilcox aquifer from combined-cycle-plant withdrawals at the Magnolia site, Benton County, Mississippi.

13. Simulated potentiometric surface change in the Lower Wilcox aquifer from combined-cycle-plant withdrawals at the Magnolia site, Benton County, Mississippi.

14. Simulated potentiometric surface change in the Cockfield aquifer from withdrawals by all users at the end of the combined-cycle-plant withdrawal scenario

15. Simulated potentiometric surface change in the Memphis/Sparta aquifer from withdrawals by all users at the end of the combined-cycle-plant withdrawal scenario

16. Simulated potentiometric surface change in the Fort Pillow/Lower Wilcox aquifer from withdrawals by all users at the end of the combined-cycle-plant withdrawal scenario

\section{Tables}

1. Generalized correlation chart of units of Tertiary age of the Claiborne and Wilcox Groups in Tennessee and northern Mississippi.

2. Annual average and 30-day maximum water demand at proposed combined-cycle turbine plants

3. Annual average and 30-day maximum water demand by well at the Gleason site.

4. Annual average and 30-day maximum water demand by well at the Tenaska site.

5. Summary of simulated potentiometric surface changes resulting from groundwater withdrawals at potential combined-cycle-plant sites. 


\title{
Effects of Groundwater Withdrawals Associated with Combined-Cycle Combustion Turbine Plants in West Tennessee and Northern Mississippi
}

\author{
By Connor J. Haugh
}

\section{Abstract}

The Mississippi Embayment Regional Aquifer Study groundwater-flow model was used to simulate the potential effects on future groundwater withdrawals at five powerplant sites - Gleason, Weakley County, Tennessee; Tenaska, Haywood County, Tennessee; Jackson, Madison County, Tennessee; Southaven, DeSoto County, Mississippi; and Magnolia, Benton County, Mississippi. The scenario used in the simulation consisted of a 30 -year average water-use period followed by a 30-day peak water-demand period. Effects of the powerplants on the aquifer system were evaluated by comparing the difference in simulated water levels in the aquifers at the end of the scenario ( 30 years plus 30 days) with and without the combined-cycle-plant withdrawals. Simulated potentiometric surface declines in source aquifers at potential combined-cycle-plant sites ranged from 56 feet in the upper Wilcox aquifer at the Magnolia site to 20 feet in the Memphis aquifer at the Tenaska site. The affected areas in the source aquifers at the sites delineated by the 4 -foot potentiometric surface-decline contour ranged from 11,362 acres at Jackson to 535,143 acres at Southaven. The extent of areas affected by potentiometric surface declines was similar at the Gleason and Magnolia sites. The affected area at the Tenaska site was smaller than the affected areas at the other sites, most likely as a result of lower withdrawal rates and greater aquifer thickness. The extent of effect was smallest at the Jackson site, where the nearby Middle Fork Forked Deer River may act as a recharge boundary. Additionally, the Jackson site lies in the Memphis aquifer outcrop area where model-simulated recharge rates are higher than in areas where the Memphis aquifer underlies less permeable deposits.

The potentiometric surface decline in aquifers overlying or underlying a source aquifer was generally 2 feet or less at all the sites except Gleason. At the Gleason site, withdrawals from the Memphis aquifer resulted in declines of as much as 9 feet in the underlying Fort Pillow aquifer. The simulated potentiometric surface change occurring in the Fort Pillow aquifer appears to be the result of leakage through the Flour Island Formation separating the Memphis and Fort Pillow aquifers where this confining unit is thin, sandy, or absent.

\section{Introduction}

As demand for electrical power increases, so does the need for water to operate electrical generation facilities. To meet rising electrical demands, the Tennessee Valley Authority (TVA) is considering the use of existing combined-cycle plants in West Tennessee and northern Mississippi and the conversion of simple-cycle plants to combined-cycle operation. The plants use groundwater for emission control and for cooling. Simple-cycle plants can use as much as about 300 gallons per minute (gal $/ \mathrm{min}$ ) of water, and combinedcycle plants can use as much as $4,000 \mathrm{gal} / \mathrm{min}$, depending on plant megawatt capacity. Depending on location, local groundwater conditions, and the aquifers used by the plants, the use of groundwater for the combined-cycle plants could affect groundwater levels in nearby domestic and municipal wells. Given these considerations, the effects of groundwater withdrawals at combined-cycle turbine plants on the aquifers and on groundwater levels are being evaluated.

In 2008, the U.S. Geological Survey (USGS), in cooperation with TVA, began an investigation to define the potential effects of groundwater withdrawals associated with combinedcycle-turbine-plant operation on the Mississippi embayment aquifer system in West Tennessee and northern Mississippi. In these areas, groundwater is the sole source of water for municipal and industrial supply. The primary sources of groundwater are the Memphis and Fort Pillow aquifers, which are the two principal aquifers of the Mississippi embayment aquifer system in West Tennessee (Parks and Carmichael, $1989,1990)$. Self-supplied domestic groundwater typically is produced from shallow zones including the terrace deposits or Cockfield aquifer, which constitute the "water-table" aquifer(s) at many locations. The Mississippi Embayment Regional Aquifer Study (MERAS) was recently completed as part of the Groundwater Resources Program of the USGS to assess groundwater availability within the Mississippi embayment. The MERAS groundwater-flow model was the primary tool used in the assessment of groundwater availability (Clark and Hart, 2009). 


\section{Purpose and Scope}

This report presents an analysis of the potential effects of groundwater withdrawals at the following five sites: Gleason, Weakley County, Tennessee; Tenaska, Haywood County, Tennessee; Jackson, Madison County, Tennessee; Southaven, DeSoto County, Mississippi; and Magnolia, Benton County, Mississippi (fig. 1). The effects of groundwater withdrawals at plant sites, in conjunction with existing withdrawals, were analyzed using the MERAS regional groundwater-flow model (Clark and Hart, 2009). Local grid refinement (LGR; Mehl and Hill, 2005) was added to the MERAS model for a more detailed analysis at two of the sites. Water-use estimates for the plant sites were provided by TVA. Water-use trends and population-growth projections were used to estimate future water demands from existing withdrawals.

\section{Approach}

The effects of groundwater withdrawals were simulated for the locations of five prospective combined-cycle plants for a 30-year period of average water use followed by a 30-day period of peak water use. Groundwater withdrawals at each of the sites were simulated using the MERAS groundwaterflow model beginning in 2007. Water use by the combinedcycle combustion plants was assumed to be constant over the 30 -year period. Projections of future water-supply withdrawals were estimated assuming a linear growth of 2 percent per year. Six stress periods of 5 years each plus a 30-day stress period were used for model simulations. At the end of the 30-year simulation period, an additional short-term stress period of 30 days followed using the projected 30-day peak water withdrawals at the plant sites. Effects of the powerplants on the aquifer system were evaluated by comparing the difference in simulated water levels in the aquifers at the end of the scenario (30 years plus 30 days) with and without the combined-cycleplant withdrawals.

The grid-cell size of the MERAS flow model is 1 square mile $\left(\mathrm{mi}^{2}\right)$ [1 mile (mi) by $\left.1 \mathrm{mi}\right]$. A more detailed local evaluation was simulated for the Gleason and Tenaska sites using a refined model grid generated with the LGR package (Mehl and Hill, 2005). The grid-cell size of the local models is $0.04 \mathrm{mi}^{2}$ ( $0.2 \mathrm{mi}$ by $0.2 \mathrm{mi}$ ).

\section{Study Area}

The simulated sites in West Tennessee and northern Mississippi lie in the gently rolling terrain of the Gulf Coastal Plain Physiographic Province (Fenneman, 1938). Land-surface altitudes range from about 200 feet (ft) near the Mississippi River to more than $500 \mathrm{ft}$ in the upland hills in the eastern part of the study area. Average annual precipitation ranges from about 50 to 54 inches and is uniformly distributed throughout the year. The mean annual temperature is about 59 degrees Fahrenheit $\left({ }^{\circ} \mathrm{F}\right)$. Mean summer temperature is about $79^{\circ} \mathrm{F}$, and mean winter temperature is about $40^{\circ} \mathrm{F}$ (National Oceanic and Atmospheric Administration, 2002).

Regional aquifers in the area are part of the Mississippi embayment aquifer system. The regional aquifers are formed by deposits of Tertiary age that make up the Claiborne and Wilcox Groups (table 1). In Tennessee, the aquifer system includes, in descending order, the following units: the Cockfield Formation (Cockfield or upper Claiborne aquifer) of the Claiborne Group, the Memphis Sand (Memphis or middle and lower Claiborne aquifer) of the Claiborne Group, and the Fort Pillow Sand (Fort Pillow aquifer) of the Wilcox Group. In northern Mississippi, the aquifer system includes, in descending order, the Cockfield Formation (Cockfield aquifer), the Sparta Sand (Sparta aquifer) of the Claiborne Group, and underlying sands of the Claiborne and Wilcox Groups that make up the lower Claiborne-upper Wilcox aquifer and the lower Wilcox aquifer (Hosman and Weiss, 1991).

\section{Regional Model}

The MERAS model covers $97,000 \mathrm{mi}^{2}$ and consists of 13 model layers with grid cells of $1 \mathrm{mi}^{2}$. The model code used for the MERAS model is MODFLOW 2005 (Harbaugh, 2005). Model layers correspond to aquifers and confining units from land surface down to the top of the Midway Group. In Tennessee these layers include the following aquifers: the fluvial deposits aquifer, the Cockfield aquifer, the Memphis aquifer, and the Fort Pillow aquifer. The MERAS model simulations span more than 130 years from 1870 to 2007 and incorporate the most current water-use data available (Clark and Hart, 2009).

\section{Water-Use Trends}

Groundwater use for the next 30 years was estimated on the basis of historic trends and population-growth projections. Nationwide, withdrawals for irrigation increased from 1950 to 1980 but have stabilized since 1985 . This stabilization in irrigation withdrawals can be attributed to climate, crop type, advances in irrigation efficiency, and higher energy costs (Hutson and others, 2004). Groundwater use for public supply in Tennessee for the 30-year period from 1970 through 2000 increased at an average annual rate of 2.4 percent. During this time, the average annual rate of growth of groundwater withdrawal for public supply slowed, with average annual rates of 2.8 percent from 1970 to $1980,2.5$ percent from 1980 to 1990 , and 1.9 percent from 1990 to 2000 (Webbers, 2003). Future groundwater withdrawals for public supply also were estimated using population projections (University of Tennessee, 2003). Population projections for 5-year increments for the period 2010 to 2040 for each municipality in West Tennessee were multiplied by the current per capita water use of each public water-supply system to estimate future groundwater 

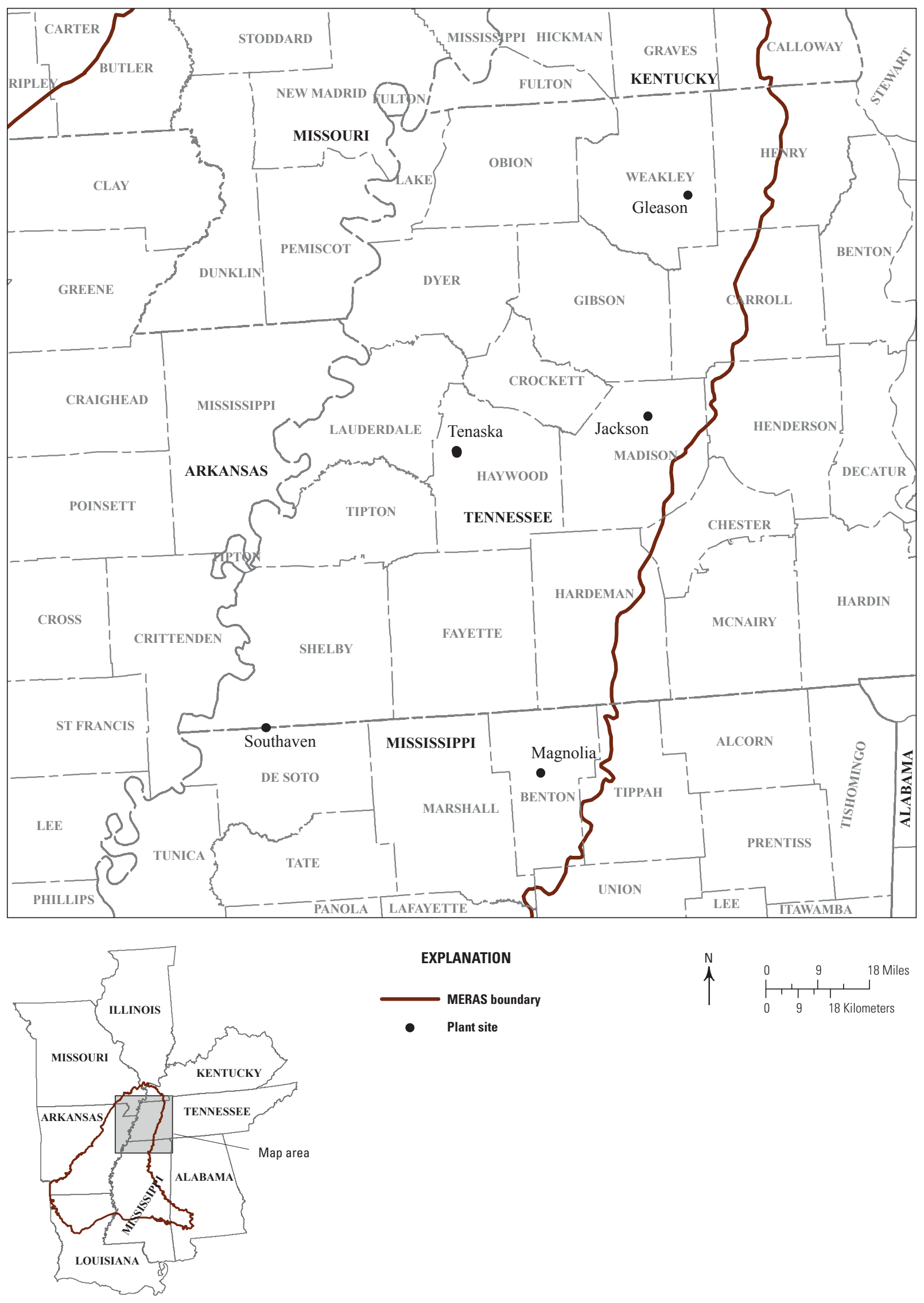

Figure 1. Locations of potential combined-cycle turbine plants in Tennessee and Mississippi. 
Table 1. Generalized correlation chart of units of Tertiary age of the Claiborne and Wilcox Groups in Tennessee and northern Mississippi.

[Fm, Formation]

\begin{tabular}{|c|c|c|c|c|c|}
\hline System & Series & Group & Tennessee & Northern Mississippi & $\begin{array}{c}\text { Regional hydrogeologic } \\
\text { unit }\end{array}$ \\
\hline \multirow{10}{*}{ Tertiary } & \multirow{6}{*}{ Eocene } & \multirow{5}{*}{ Claiborne } & $\begin{array}{l}\text { Cockfield Fm } \\
\text { (Cockfield aquifer) }\end{array}$ & $\begin{array}{l}\text { Cockfield Fm } \\
\text { (Cockfield aquifer) }\end{array}$ & Upper Claiborne aquifer \\
\hline & & & Cook Mountain Fm & Cook Mountain Fm & $\begin{array}{l}\text { Middle Claiborne } \\
\text { confining unit }\end{array}$ \\
\hline & & & \multirow{3}{*}{$\begin{array}{l}\text { Memphis Sand } \\
\text { (Memphis aquifer) }\end{array}$} & $\begin{array}{l}\text { Sparta Sand } \\
\text { (Sparta aquifer) }\end{array}$ & Middle Claiborne \\
\hline & & & & Zilpha Clay & $\begin{array}{l}\text { Lower } \\
\text { Claiborne } \\
\text { confining } \\
\text { unit }\end{array}$ \\
\hline & & & & $\begin{array}{l}\text { Lower sands in the } \\
\text { Claiborne Group }\end{array}$ & \multirow{2}{*}{$\begin{array}{l}\text { Lower Claiborne- } \\
\text { Upper Wilcox aquifer }\end{array}$} \\
\hline & & \multirow{3}{*}{ Wilcox } & Flour Island Fm & $\begin{array}{l}\text { Upper sands in the } \\
\text { Wilcox Group }\end{array}$ & \\
\hline & \multirow{4}{*}{ Paleocene } & & $\begin{array}{l}\text { Fort Pillow Sand } \\
\text { (Fort Pillow aquifer) }\end{array}$ & \multirow{2}{*}{$\begin{array}{l}\text { Lower sands in the } \\
\text { Wilcox Group }\end{array}$} & Middle Wilcox aquifer \\
\hline & & & Old Breastworks Fm & & Lower Wilcox aquifer \\
\hline & & \multirow{2}{*}{ Midway } & Porters Creek Clay & Porters Creek Clay & \multirow{2}{*}{ Midway confining unit } \\
\hline & & & Clayton Fm & Clayton Fm & \\
\hline
\end{tabular}

Modified from Hosman and Weiss, 1991.

demand. The average annual rate of growth for all public groundwater supplies in West Tennessee was 0.7 percent with most individual public-supply systems ranging from 0 to 1.2 percent. Combining the two approaches, withdrawals for public groundwater use were assumed to increase at an average annual rate of 2 percent. Groundwater withdrawals for irrigation were assumed to remain constant at 2007 levels.

\section{Effects of Groundwater Withdrawals}

The effects of groundwater withdrawals associated with the operation of combined-cycle turbine plants were evaluated by comparing simulations with and without pumping at the five plant sites (table 2). The differences in water levels between these two simulations were contoured to provide an overall measure of effects (figs. 2 and 3; table 3).
Table 2. Annual average and 30-day maximum water demand at proposed combined-cycle turbine plants.

[gal/min, gallons per minute]

\begin{tabular}{llccc}
\hline Plant & \multicolumn{1}{c}{ Source } & aquifer & $\begin{array}{c}\text { Annual } \\
\text { of wells } \\
\text { average } \\
\text { water } \\
\text { demand } \\
\text { (gal/min) }\end{array}$ & $\begin{array}{c}\text { 30-day } \\
\text { maximum } \\
\text { water } \\
\text { demand } \\
\text { (gal/min) }\end{array}$ \\
\hline Gleason & Memphis & 4 & 2,460 & 3,473 \\
Tenaska & Memphis & 5 & 1,643 & 2,315 \\
Jackson & Memphis & - & 2,460 & 3,473 \\
Southaven & Lower Wilcox & 6 & 2,460 & 3,473 \\
Magnolia & Upper Wilcox & 12 & 1,968 & 2,778 \\
& Lower Wilcox & 3 & 492 & 695 \\
\hline
\end{tabular}



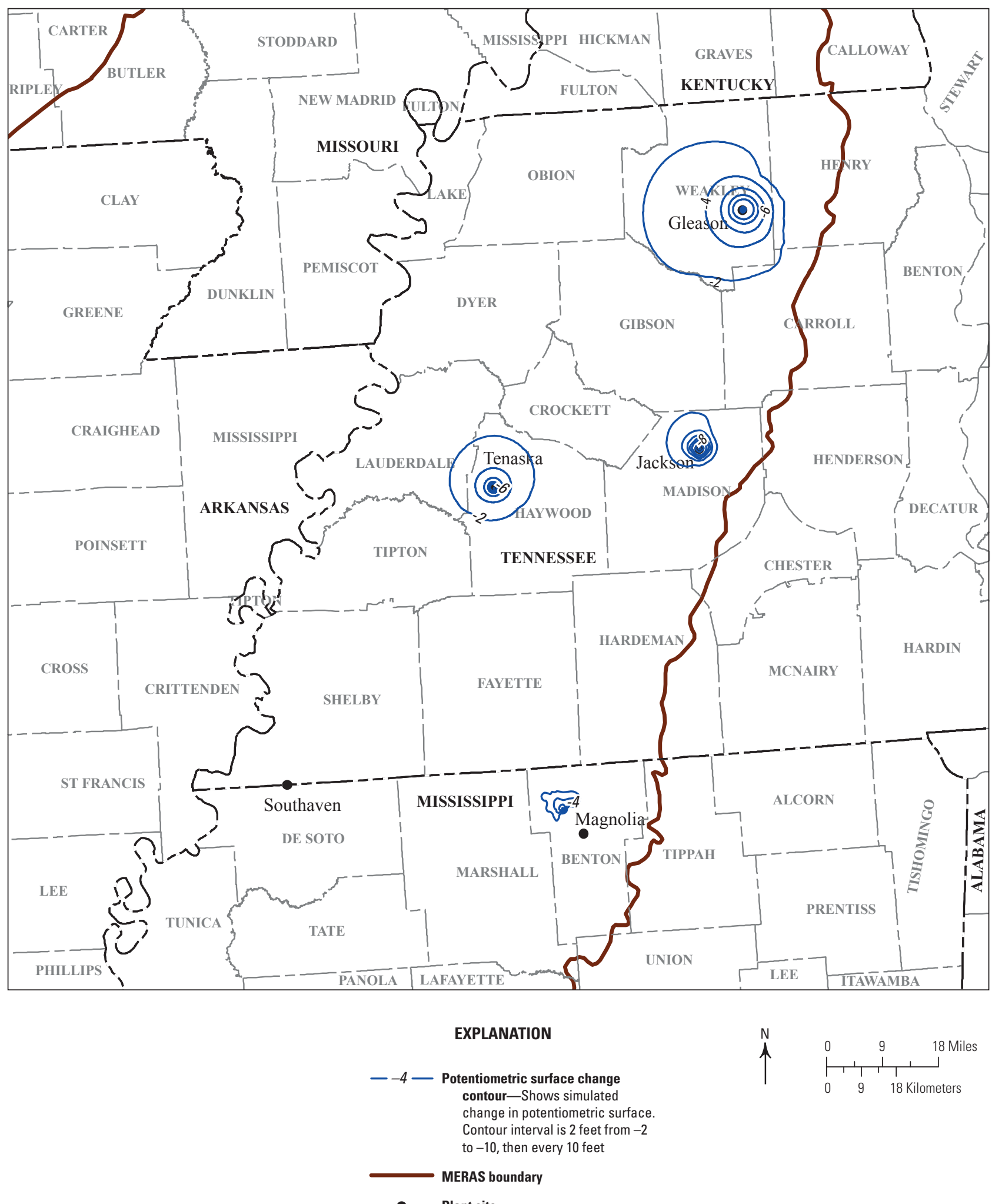

Figure 2. Simulated potentiometric surface change in the Memphis/Sparta aquifer from combined-cycle-plant withdrawals at proposed combined-cycle turbine plants. 


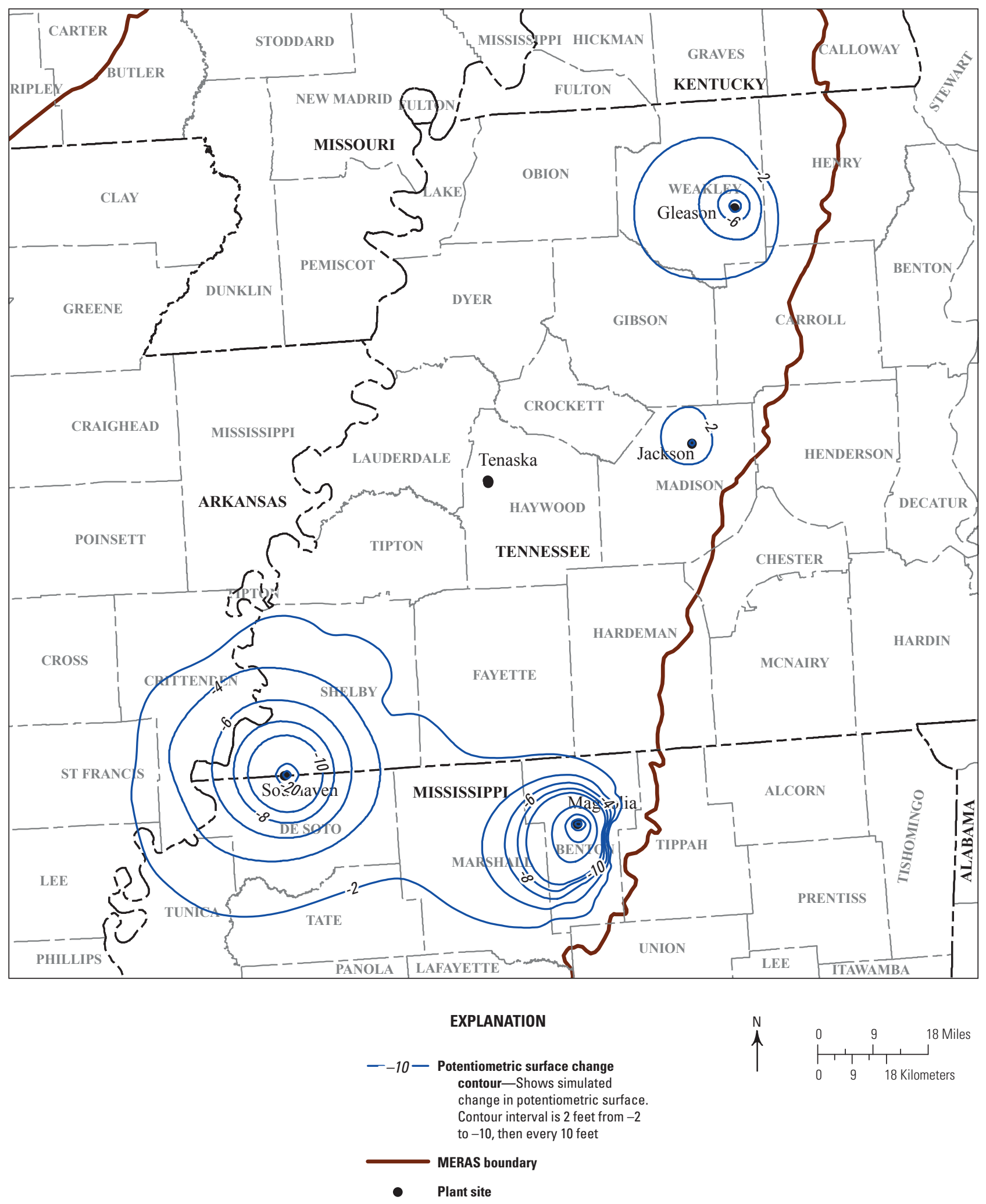

Figure 3. Simulated potentiometric surface change in the Lower Wilcox/Fort Pillow aquifer from combined-cycle-plant withdrawals at proposed combined-cycle turbine plants. 


\section{Gleason}

The Gleason site (fig. 1) is estimated to have an annual average groundwater withdrawal of $2,460 \mathrm{gal} / \mathrm{min}$ and a 30-day maximum water withdrawal of 3,473 gal $/ \mathrm{min}$ (table 2). For the simulation, four wells at the site pumped water from the Memphis aquifer (table 3). To obtain more detailed resolution in the simulation, local grid refinement was used at the Gleason site (fig. 4). At the end of the TVA withdrawal scenario, the simulated potentiometric surfaces at the plant site in the model cell containing well G5 declined by $40 \mathrm{ft}$ in the Memphis aquifer (fig. 5) and $9 \mathrm{ft}$ in the Fort Pillow aquifer (fig. 6). The simulated changes in the Fort Pillow aquifer appear to be the result of leakage through the Flour Island Formation, which separates the Memphis and Fort Pillow aquifers where the confining unit is thin, sandy, or absent.

Table 3. Annual average and 30-day maximum water demand by well at the Gleason site.

[gal/min, gallons per minute]

\begin{tabular}{llrr}
\hline & & & \\
& & & \\
\hline G-1 & Memphis & 516 & 1,000 \\
G-2 & Memphis & 48 & 473 \\
G-3 & Memphis & 896 & 1,000 \\
G-5 & Memphis & 1,000 & 1,000 \\
\hline
\end{tabular}

\section{Tenaska}

The Tenaska site (fig. 1) is estimated to have an annual average water withdrawal of $1,643 \mathrm{gal} / \mathrm{min}$ and a 30 -day maximum water withdrawal of $2,315 \mathrm{gal} / \mathrm{min}$ (table 2). For the simulation, five wells at the site pumped water from the Memphis aquifer (table 4). To obtain more detailed resolution in the simulation, local grid refinement was used at the Tenaska site (fig. 7). At the end of the TVA withdrawal scenario, simulated potentiometric surfaces at the plant site in the model cell containing well T4 declined by $20 \mathrm{ft}$ in the Memphis aquifer (fig. 8), about $1 \mathrm{ft}$ in the Cockfield aquifer, and $2 \mathrm{ft}$ in the Fort Pillow aquifer.

\section{Jackson}

The Jackson site (fig. 1) is estimated to have an annual average water withdrawal of $2,460 \mathrm{gal} / \mathrm{min}$ and a 30-day maximum water withdrawal of 3,473 $\mathrm{gal} / \mathrm{min}$ (table 2 ). For the simulation, wells at the site pumped water from the Memphis aquifer. At the end of the TVA withdrawal scenario, simulated potentiometric surfaces in the $1-\mathrm{mi}^{2}$ model cell located at the plant site declined by $35 \mathrm{ft}$ in the Memphis aquifer (fig. 9) and $4 \mathrm{ft}$ in the Fort Pillow aquifer (fig. 10). The areal extent of the decline at the Jackson site appears to be limited by a nearby recharge boundary at the Middle Fork Forked Deer River, which may provide a source of water to the aquifer. Additionally, the Jackson site lies in the Memphis aquifer outcrop where model-simulated recharge rates are higher than in areas where the Memphis aquifer underlies less permeable deposits.

Table 4. Annual average and 30-day maximum water demand by well at the Tenaska site.

[gal/min, gallons per minute]

\begin{tabular}{llcc} 
Well & Source aquifer & $\begin{array}{c}\text { Annual average } \\
\text { water demand } \\
\text { (gal/min) }\end{array}$ & $\begin{array}{c}\text { 30-day maximum } \\
\text { water demand } \\
\text { (gal/min) }\end{array}$ \\
\hline T-1 & Memphis & 538 & 758 \\
T-2 & Memphis & 0 & 0 \\
T-3 & Memphis & 373 & 526 \\
T-4 & Memphis & 690 & 972 \\
T-5 & Memphis & 42 & 59 \\
\hline
\end{tabular}

\section{Southaven}

The Southaven site (fig. 1) is estimated to have an annual average water withdrawal of 2,460 $\mathrm{gal} / \mathrm{min}$ and a 30 -day maximum water withdrawal of $3,473 \mathrm{gal} / \mathrm{min}$ (table 2 ). For the simulation, six wells at the site pumped water from the lower Wilcox aquifer (Fort Pillow aquifer equivalent). At the end of the TVA withdrawal scenario, simulated potentiometric surfaces in the $1-\mathrm{mi}^{2}$ model cell located at the plant site declined by $38 \mathrm{ft}$ in the lower Wilcox aquifer (fig. 11) and about $1 \mathrm{ft}$ in the overlying Memphis aquifer.

\section{Magnolia}

The Magnolia site (fig. 1) is estimated to have an annual average water withdrawal of $2,460 \mathrm{gal} / \mathrm{min}$ and a 30 -day maximum water withdrawal of $3,473 \mathrm{gal} / \mathrm{min}$ (table 2). For the simulation at this site, 12 wells pumped water from the upper Wilcox aquifer and 3 wells from the lower Wilcox aquifer. Pumping was apportioned between the two aquifers on the basis of the number of wells in each aquifer. At the end of the TVA withdrawal scenario, simulated potentiometric surfaces in the $1-\mathrm{mi}^{2}$ model cell located at the plant site declined by $56 \mathrm{ft}$ in the upper Wilcox aquifer (fig. 12) and $51 \mathrm{ft}$ in the lower Wilcox aquifer (fig. 13). The spatial extent of change in both aquifers is constrained to the south and east by the boundary of the aquifers. 


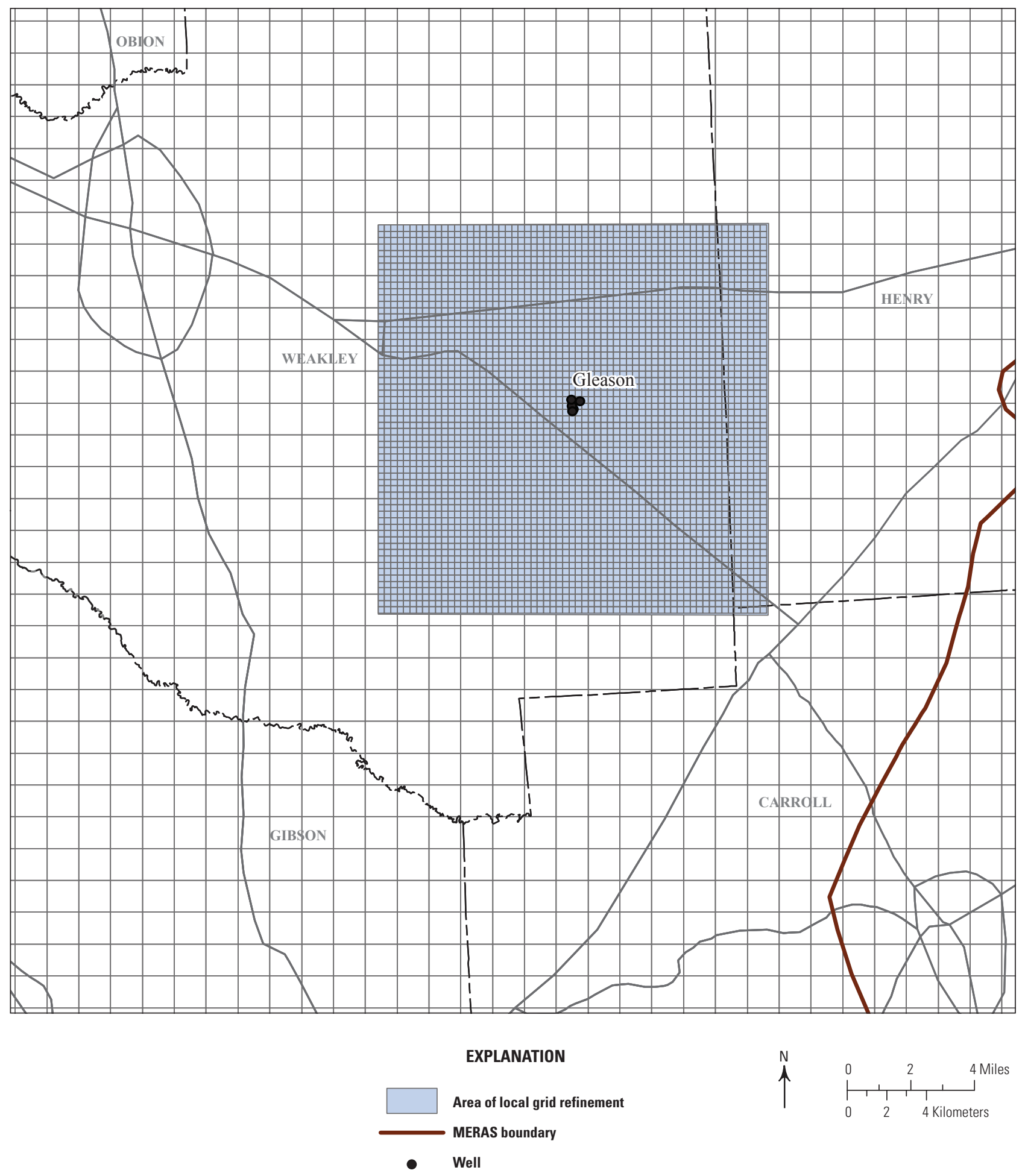

Figure 4. Local grid refinement area at the Gleason site, Weakley County, Tennessee. 


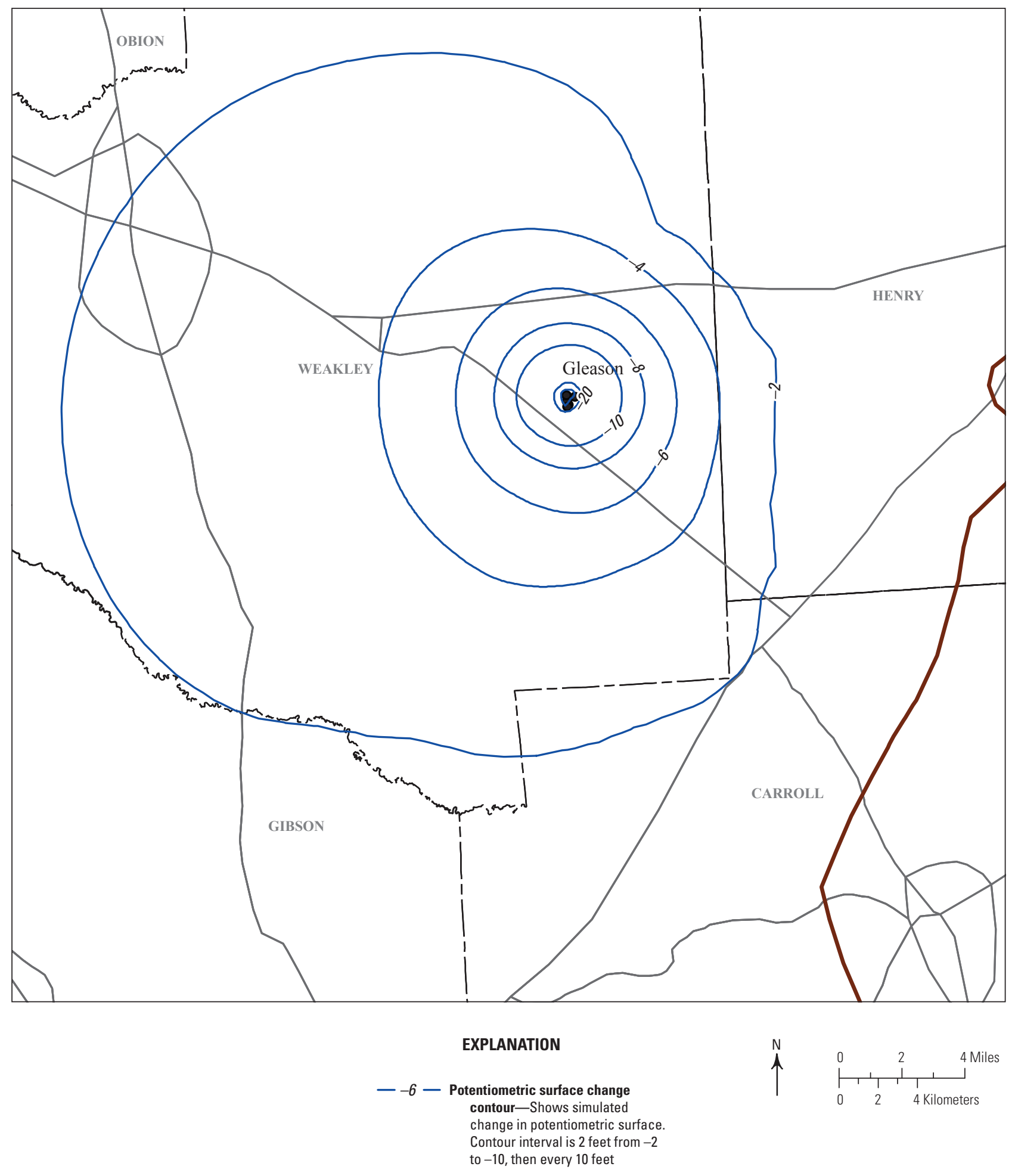

\section{MERAS boundary}

- Well

Figure 5. Simulated potentiometric surface change in the Memphis aquifer from combined-cycle-plant withdrawals at the Gleason site, Weakley County, Tennessee. 


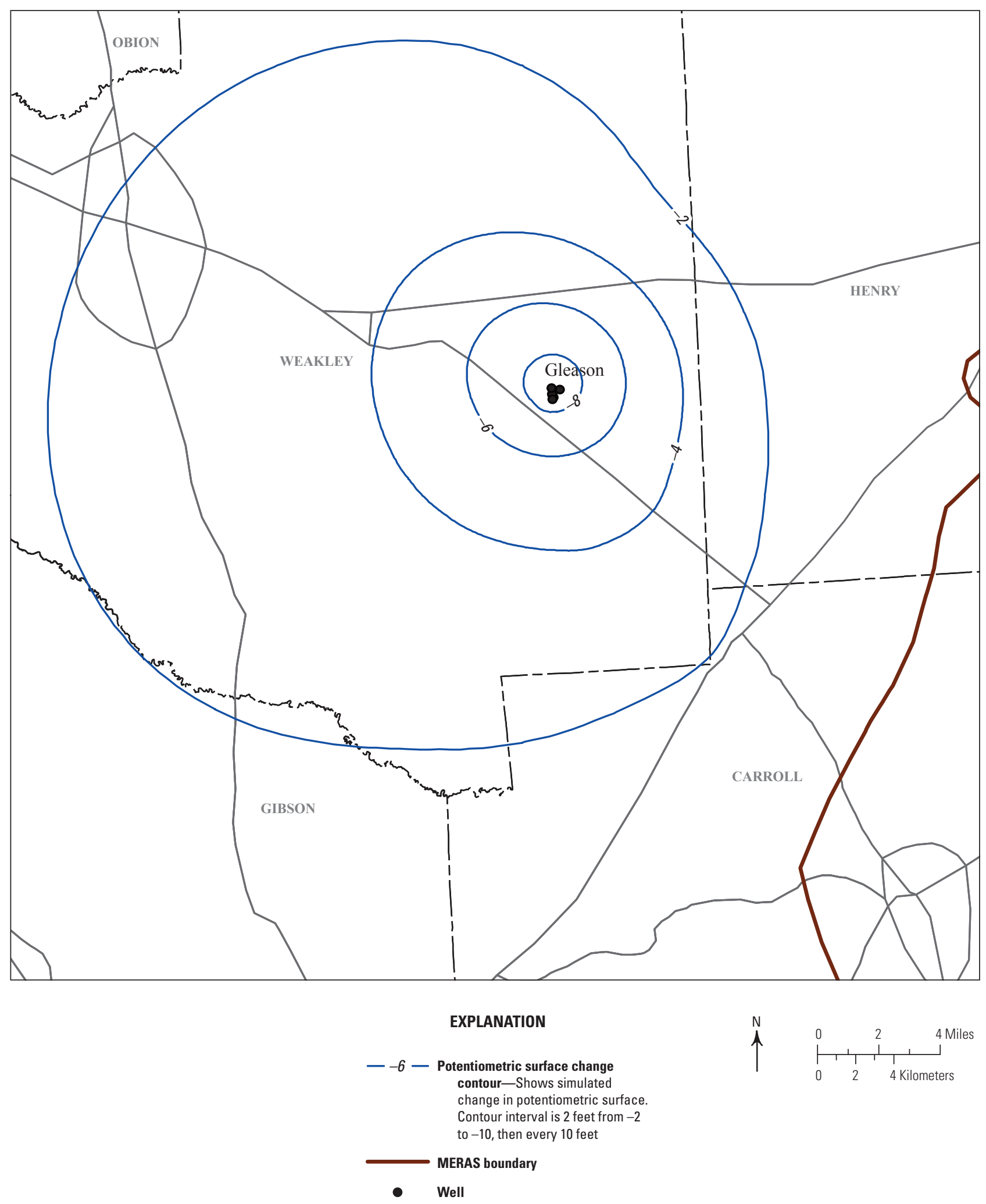

Figure 6. Simulated potentiometric surface change in the Fort Pillow aquifer from combined-cycle-plant withdrawals at the Gleason site, Weakley County, Tennessee. 


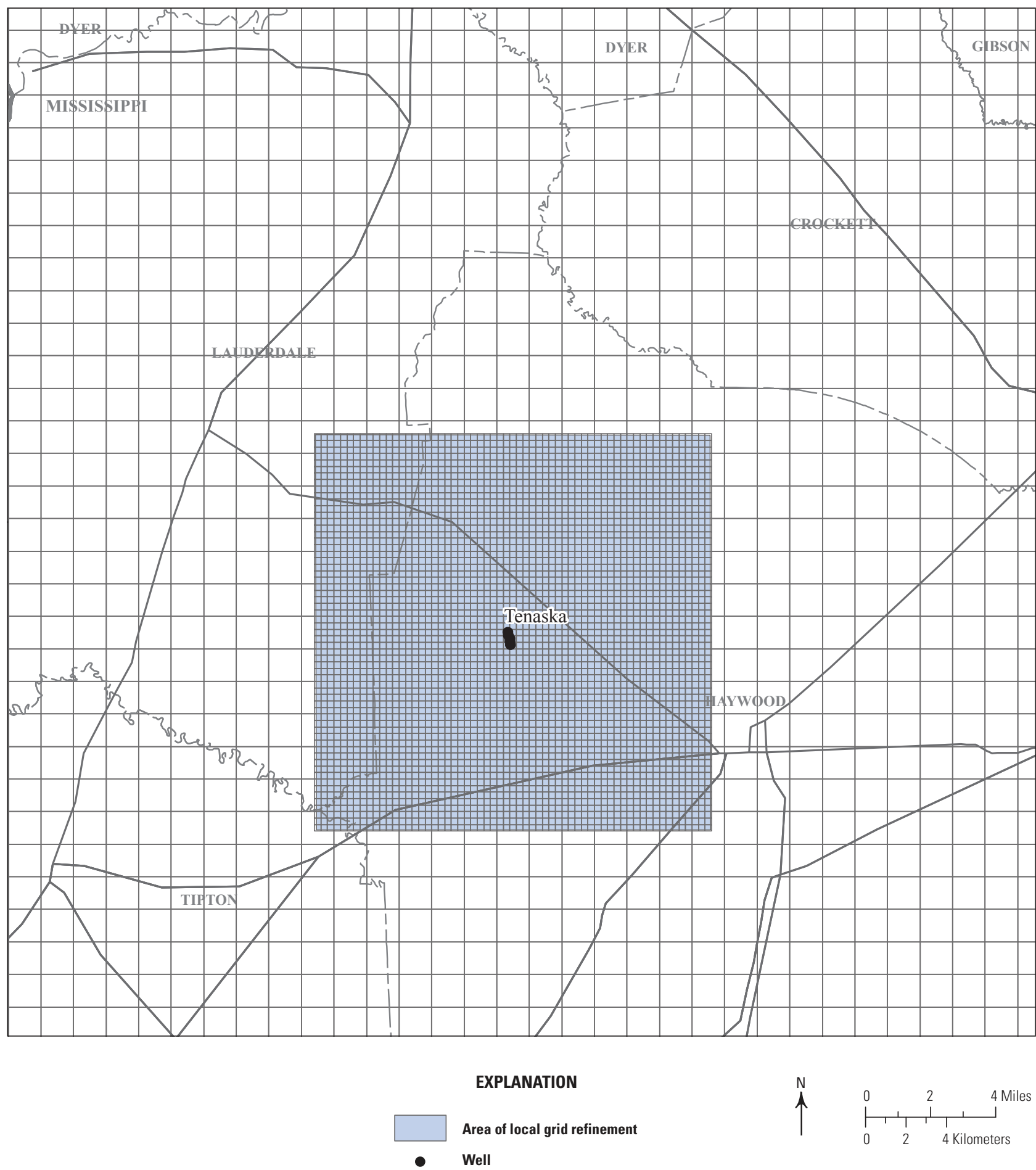

Figure 7. Local grid refinement area at the Tenaska site, Haywood County, Tennessee. 


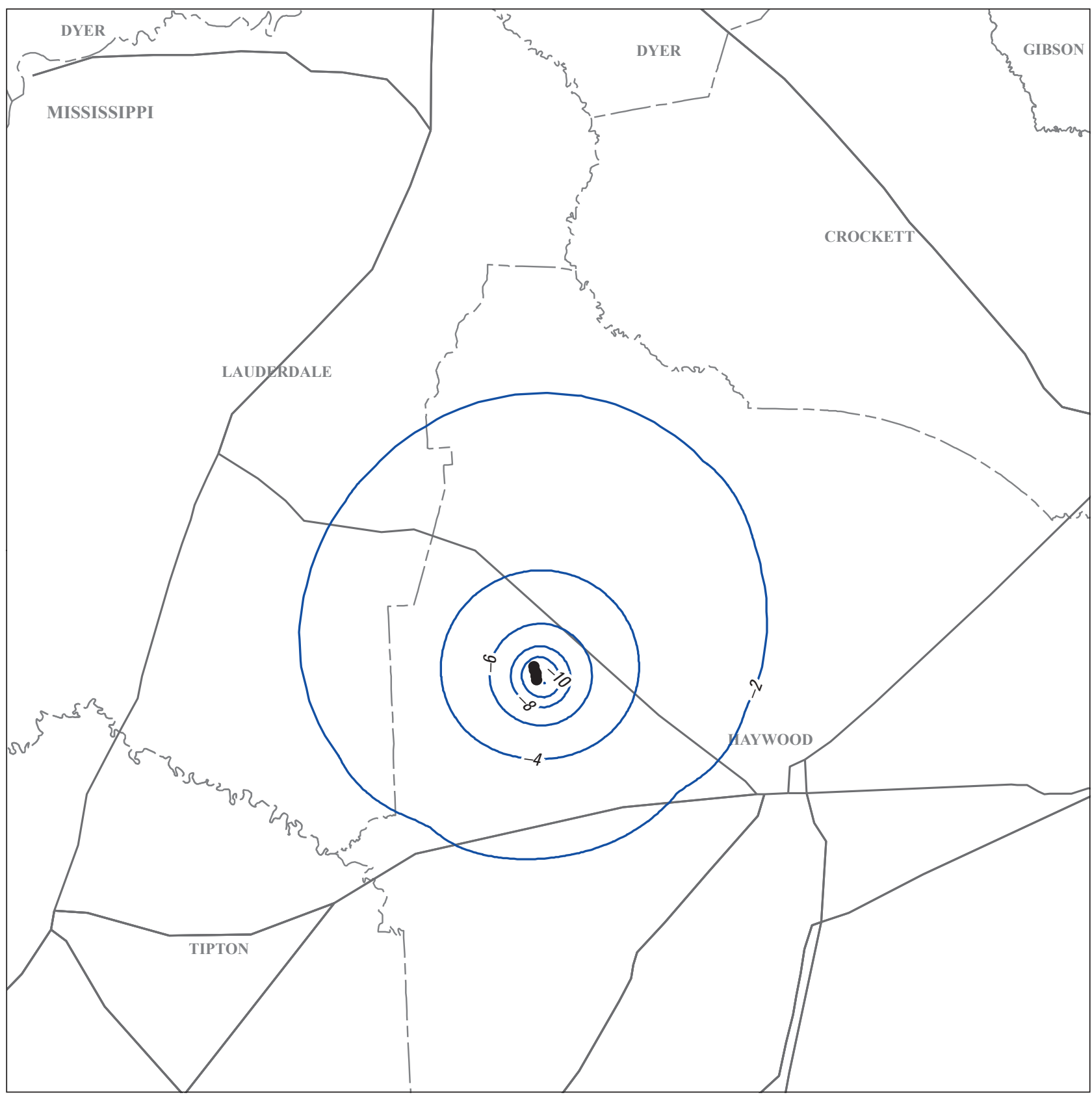

EXPLANATION
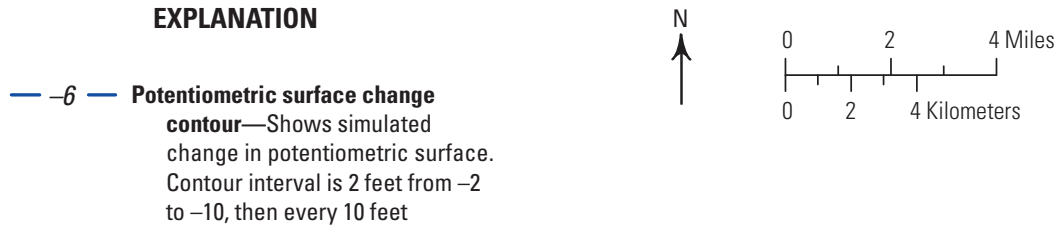

- Well

Figure 8. Simulated potentiometric surface change in the Memphis aquifer from combined-cycle-plant withdrawals at the Tenaska site, Haywood County, Tennessee. 

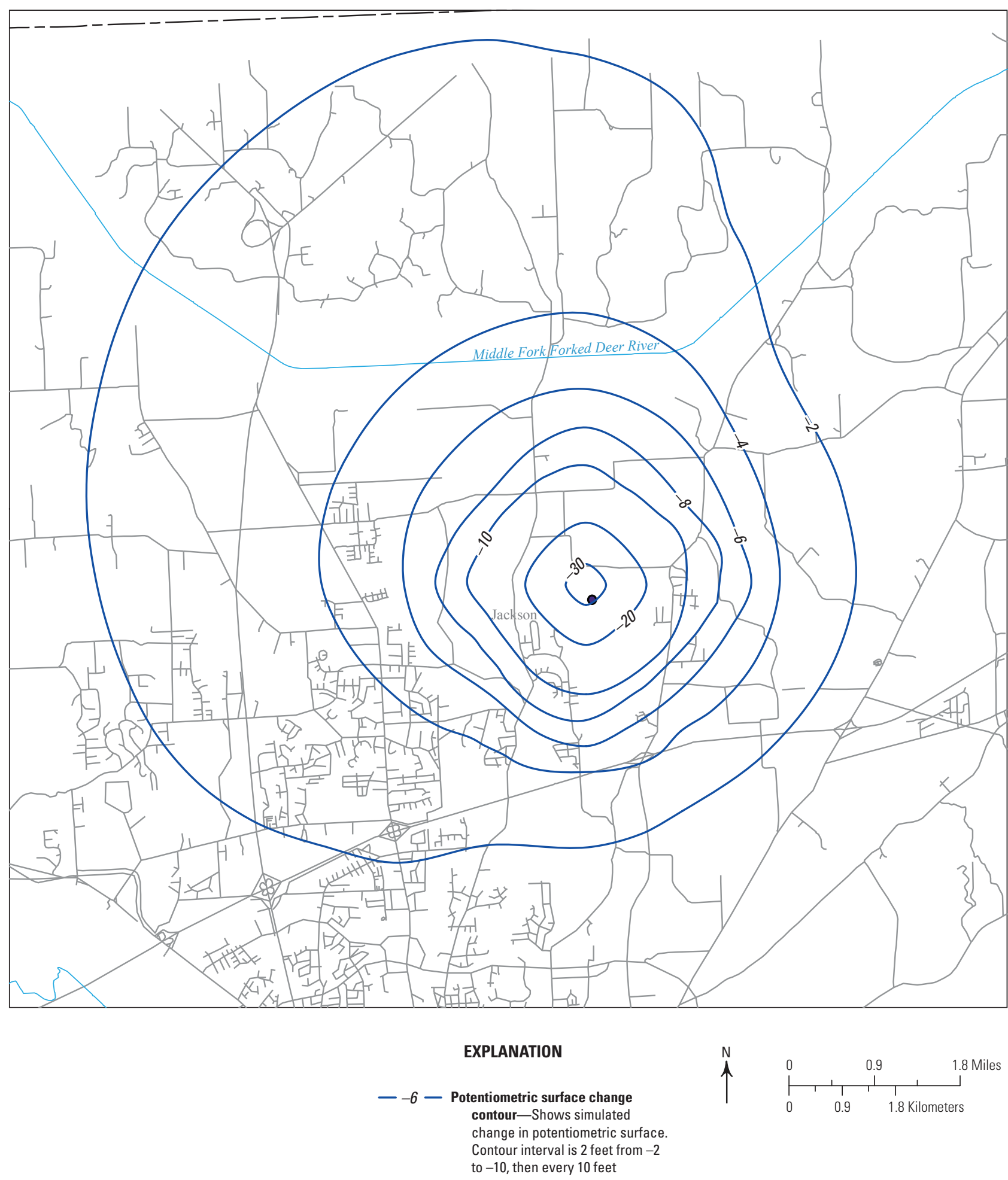

Contour interval is 2 feet from -2

to -10 , then every 10 feet

- Plant site

Figure 9. Simulated potentiometric surface change in the Memphis aquifer from combined-cycle-plant withdrawals at the Jackson site, Madison County, Tennessee. 

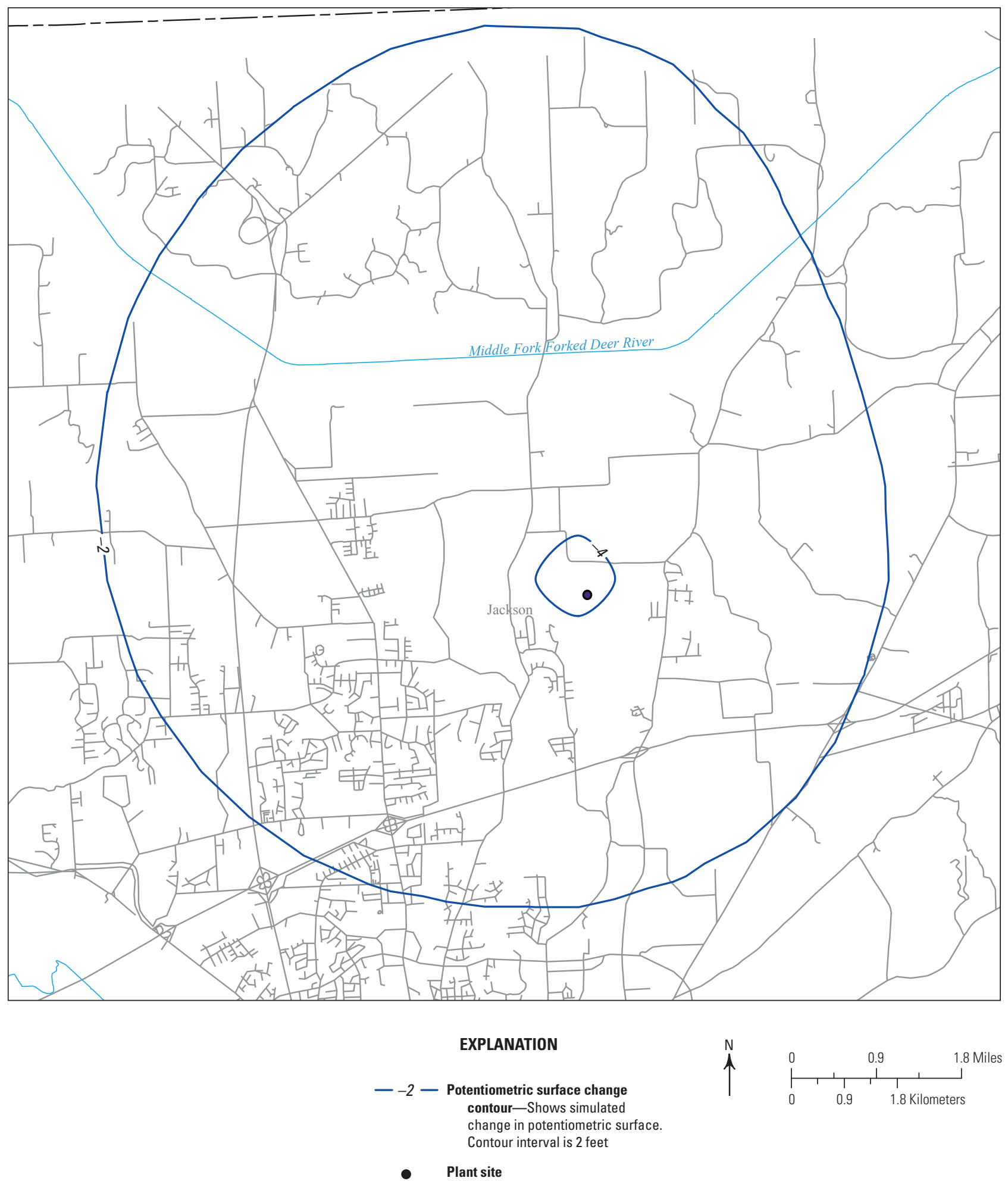

- Plant site

Figure 10. Simulated potentiometric surface change in the Fort Pillow aquifer from combined-cycle-plant withdrawals at the Jackson site, Madison County, Tennessee. 


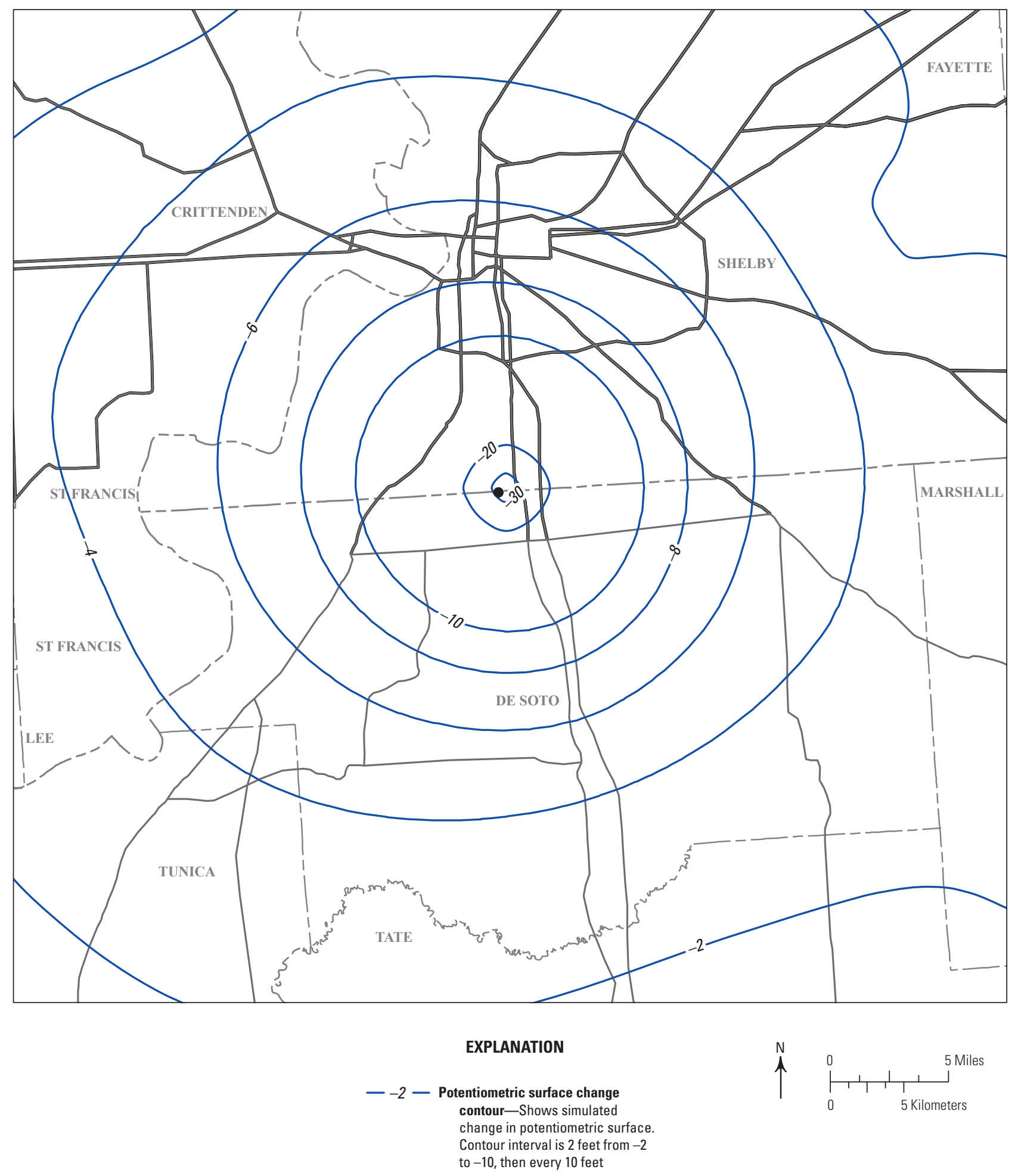

- Plant site

Figure 11. Simulated potentiometric surface change in the Lower Wilcox/Fort Pillow aquifer from combined-cycle-plant withdrawals at the Southaven site, DeSoto County, Mississippi. 

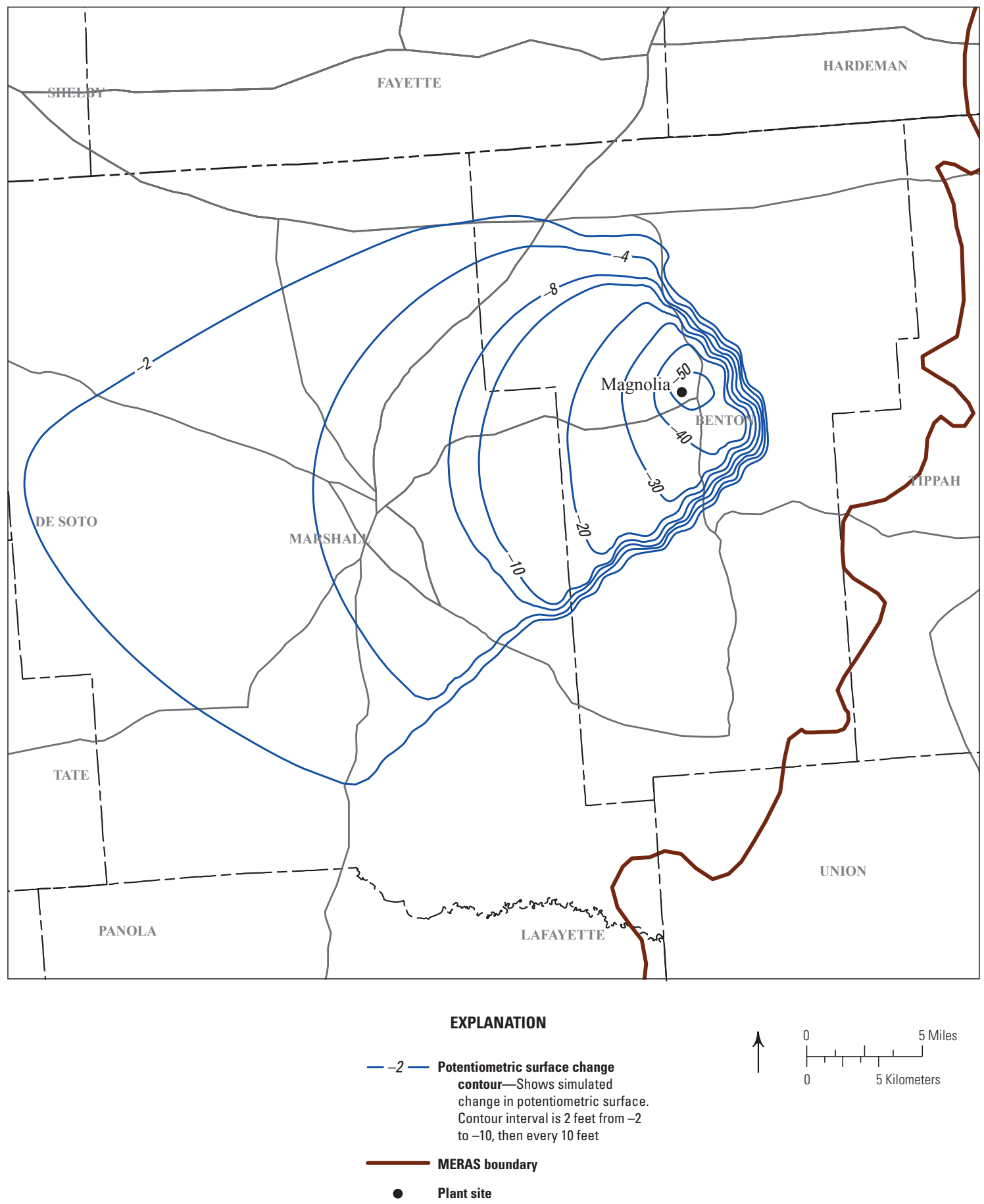

Figure 12. Simulated potentiometric surface change in the Upper Wilcox aquifer from combined-cycle-plant withdrawals at the Magnolia site, Benton County, Mississippi. 

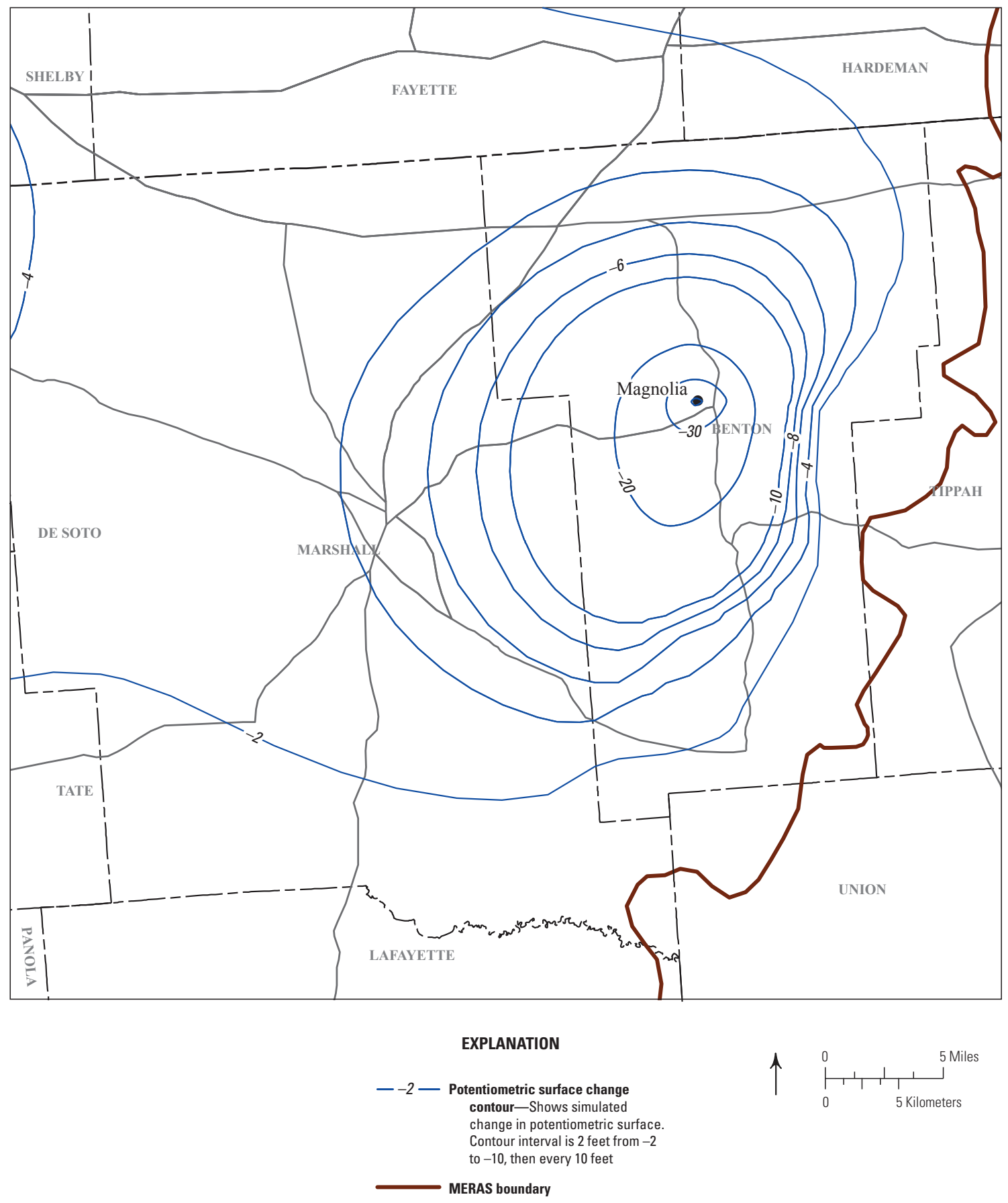

- Plant site

Figure 13. Simulated potentiometric surface change in the Lower Wilcox aquifer from combined-cycle-plant withdrawals at the Magnolia site, Benton County, Mississippi. 


\section{Discussion of Results}

Simulated potentiometric surface declines in source aquifers attributed to plant withdrawals at potential combinedcycle-plant sites ranged from a maximum of $56 \mathrm{ft}$ in the upper Wilcox aquifer at the Magnolia site to a minimum of $20 \mathrm{ft}$ in the Memphis aquifer at the Tenaska site (table 5). The areas encompassed by the $4 \mathrm{ft}$ potentiometric surfacedecline contour (affected area) ranged from a minimum of 11,362 acres at Jackson to a maximum of 535,143 acres at Southaven. The magnitude of change at these sites and the spatial extent of affected areas vary with the transmissivity and storativity of the aquifers, the degree of confinement above and below the aquifers, the modeled withdrawal rates, and the effects of nearby boundary conditions. The overall extents of affected areas are similar at the Gleason and Magnolia sites. The more limited extent of effect at the Tenaska site is most likely a result of the relatively low withdrawal rates and greater aquifer thickness at Tenaska. The spatial extent of effect was least at the Jackson site where the presence of the Middle Fork Forked Deer River nearby may act as a recharge boundary. Additionally, the Jackson site lies in the Memphis aquifer outcrop where modeled recharge rates are higher than in areas where the Memphis aquifer underlies less permeable deposits.

The simulated potentiometric surface in aquifers overlying or underlying source aquifers generally declined less than $2 \mathrm{ft}$ at all the sites except Gleason. At the Gleason site, withdrawals from the Memphis aquifer resulted in a decline of about $9 \mathrm{ft}$ in the underlying Fort Pillow aquifer-perhaps the result of leakage through the Flour Island Formation separating the Memphis and Fort Pillow aquifers where this confining unit is thin, sandy, or absent.

Simulated declines in potentiometric surfaces from TVA withdrawals were similar in magnitude and extent to larger patterns of decline associated with all users over the simulation period. Simulated declines in the Cockfield aquifer from all groundwater use ranged from less than $10 \mathrm{ft}$ to about $70 \mathrm{ft}$ with the largest declines occurring in Shelby County, Tenn. (fig. 14). Simulated declines in the Memphis/Sparta aquifer from all groundwater use ranged from less than $10 \mathrm{ft}$ to about $80 \mathrm{ft}$ with the largest declines occurring in Shelby County, Tenn. (fig. 15). Simulated potentiometric surface declines in the Fort Pillow/lower Wilcox aquifer from all groundwater use ranged from less than $10 \mathrm{ft}$ to about $90 \mathrm{ft}$ with the largest declines occurring in Crittenden County, Ark. (fig. 16).

\section{Model Limitations}

Models are simplifications of natural systems. Factors that affect how well a model represents a given natural system include the model scale; the accuracy and availability of hydraulic property data; the accuracy of pumping, water level, and streamflow data; and appropriately defined boundary conditions. The MERAS model, used for the analysis presented in this report, is consistent with the conceptual model and hydrologic data of the MERAS study area. The MERAS model uses a grid-cell size of $1 \mathrm{mi}^{2}$. The local grid refinement used in the Tenaska and Gleason areas use a grid-cell size of $0.04 \mathrm{mi}^{2}$. A model will not provide an accurate prediction on a scale smaller than the grid resolution. The hydraulicconductivity zones used in the model represent large-scale variation in hydraulic properties; the actual spatial variations of hydraulic properties of the aquifer system occur on a much smaller scale and are poorly defined. Further discussion of the limitations of the MERAS model are reported by Clark and Hart (2009, p. 56).

Table 5. Summary of simulated potentiometric surface changes resulting from groundwater withdrawals at potential combinedcycle-plant sites.

[TVA, Tennessee Valley Authority]

\begin{tabular}{lccc}
\hline & \multicolumn{2}{c}{$\begin{array}{r}\text { Simulated potentiometric surface change from } \\
\text { the TVA withdrawal scenario }\end{array}$} \\
& $\begin{array}{c}\text { Memphis } \\
\text { at potential combined-cycle-plant sites (in feet) }\end{array}$ & $\begin{array}{c}\text { Upper } \\
\text { Wilcox }\end{array}$ & $\begin{array}{c}\text { Fort Pillow/ } \\
\text { lower Wilcox }\end{array}$ \\
\hline Gleason & -40 & - & -9 \\
Tenaska & -20 & - & -2 \\
Jackson & -35 & - & -4 \\
Southaven & -1 & - & -38 \\
Magnolia & - & -56 & -51 \\
\hline
\end{tabular}




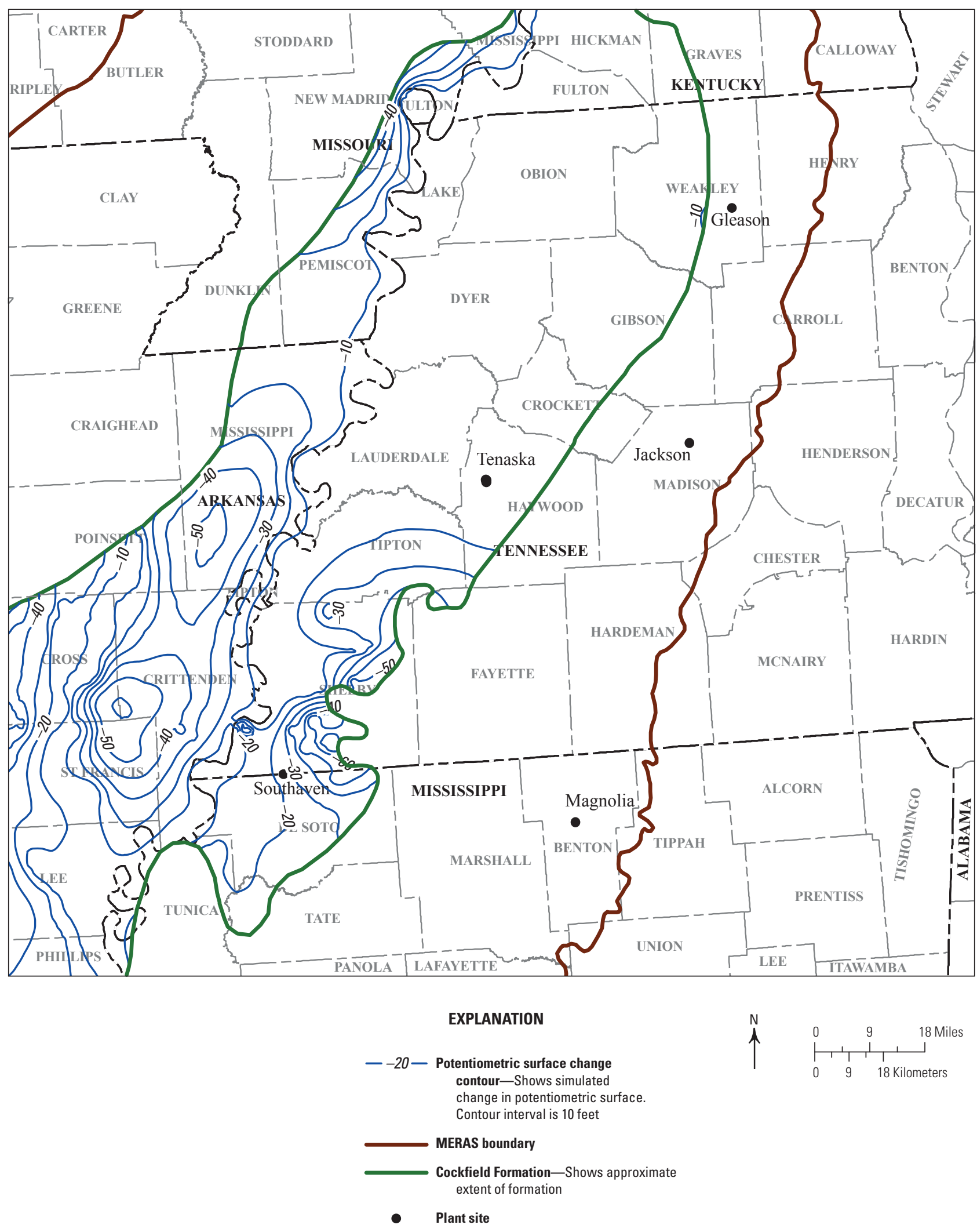

Figure 14. Simulated potentiometric surface change in the Cockfield aquifer from withdrawals by all users at the end of the combined-cycle-plant withdrawal scenario. 

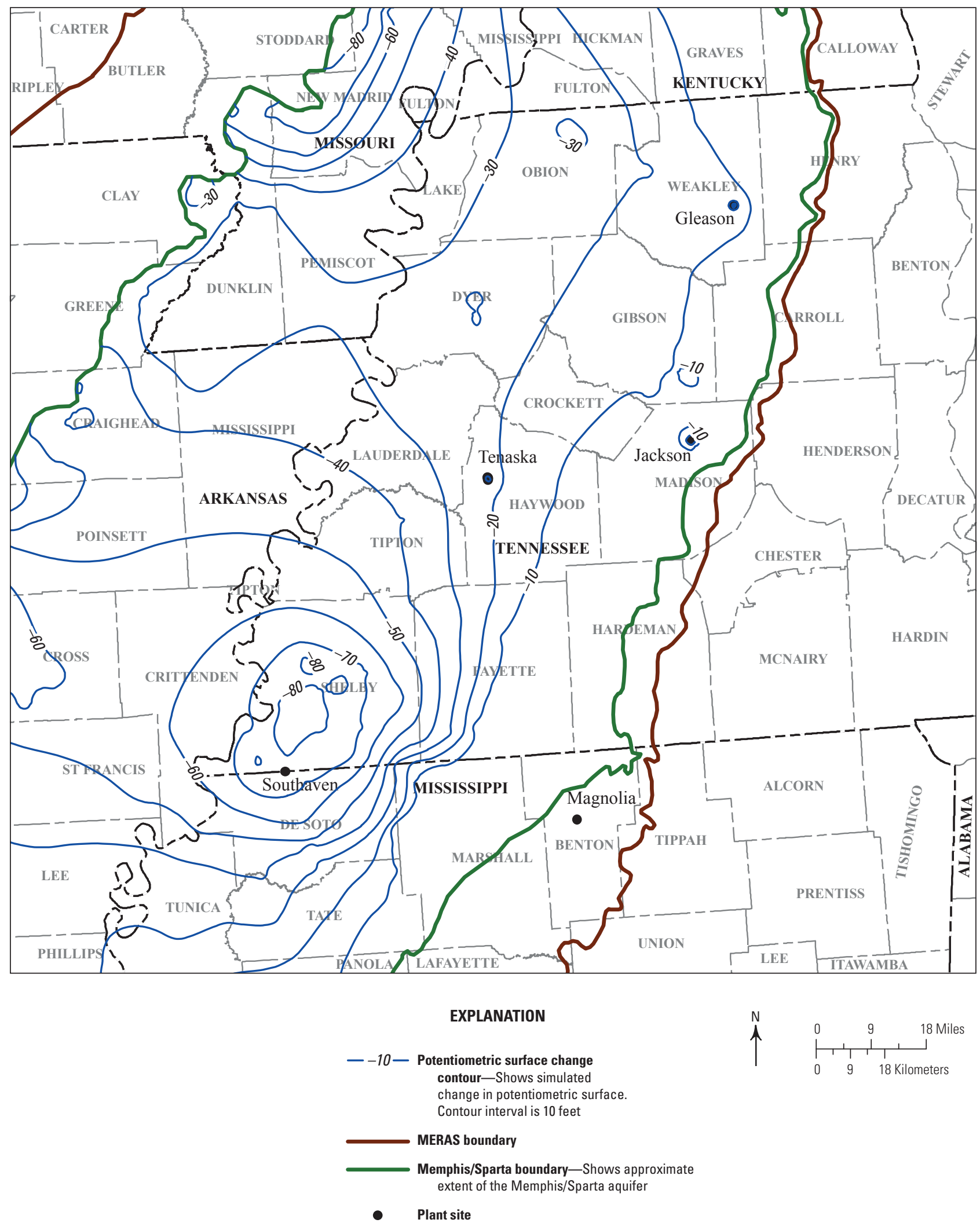

Figure 15. Simulated potentiometric surface change in the Memphis/Sparta aquifer from withdrawals by all users at the end of the combined-cycle-plant withdrawal scenario. 

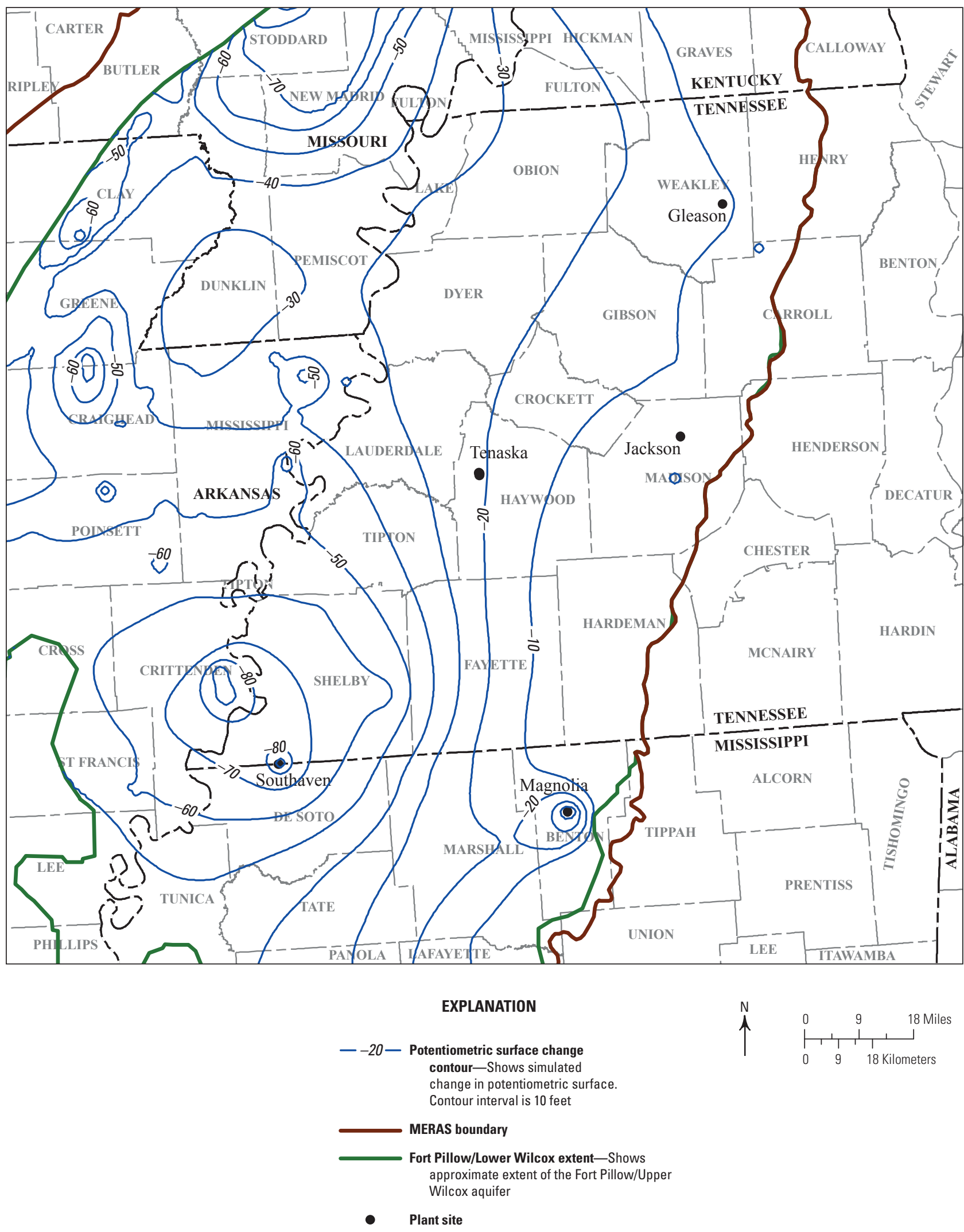

change in potentiometric surface.

ERAS boundary

approximate extent of the Fort Pillow/Upper Wilcox aquifer

Figure 16. Simulated potentiometric surface change in the Fort Pillow/Lower Wilcox aquifer from withdrawals by all users at the end of the combined-cycle-plant withdrawal scenario. 


\section{Summary}

Increases in population have brought about corresponding increases in demand for electric power. The Tennessee Valley Authority is considering the use of one or more existing combined-cycle plants in West Tennessee and northern Mississippi and the potential conversion of simple-cycle plants to combined-cycle operation. The combined-cycle plants, depending on electrical generation capacity, may require relatively large amounts of water for operation. Given these considerations, the effects of groundwater withdrawals at combined-cycle turbine plants on the aquifers and on groundwater levels are being evaluated.

The potential effects of increased groundwater withdrawals were simulated using the MERAS regional groundwaterflow model at five sites: Gleason, Weakley County, Tennessee; Tenaska, Haywood County, Tennessee; Jackson, Madison County, Tennessee; Southaven, DeSoto County, Mississippi; and Magnolia, Benton County, Mississippi. The scenario evaluated consisted of a 30-year average water-use period followed by a 30-day peak water-demand period. Projections of future water use by public utilities were estimated assuming a linear growth in demand of 2 percent per year. Effects of the powerplants on the aquifer system were evaluated by comparing the difference in simulated water levels in the aquifers at the end of the scenario ( 30 years plus 30 days) with and without the combined-cycle-plant withdrawals.

Simulated declines in the potentiometric surface in source aquifers at potential combined-cycle-plant sites ranged from $56 \mathrm{ft}$ in the upper Wilcox aquifer at the Magnolia site to $20 \mathrm{ft}$ in the Memphis aquifer at the Tenaska site. The spatial extent of declines as delineated by the minus 4-ft potentiometric surface change contour ranged from 11,362 acres at Jackson to 535,143 acres at Southaven.

The simulated potentiometric surface declines in aquifers overlying or underlying source aquifers generally were less than $2 \mathrm{ft}$ at all the sites except Gleason. At the Gleason site, withdrawals from the Memphis aquifer result in potentiometric surface declines of about $9 \mathrm{ft}$ in the underlying Fort Pillow aquifer. Overall, declines in potentiometric surfaces resulting from combined-cycle powerplants would not appear to be unusual compared to those associated with other projected uses in the region.

\section{Selected References}

Clark, B.R., and Hart, R.M., 2009, The Mississippi Embayment Regional Aquifer Study (MERAS)_Documentation of a groundwater-flow model constructed to assess water availability in the Mississippi Embayment: U.S. Geological Survey Scientific Investigations Report 2009-5172, 61 p.

Fenneman, N.M., 1938, Physiography of the eastern United States: New York and London, McGraw-Hill Book Company, $714 \mathrm{p}$.

Harbaugh, A.W., 2005, MODFLOW-2005, the U.S. Geological Survey modular ground-water model-The ground-water flow process: U.S. Geological Survey Techniques and Methods 6-A16, variously paged.

Hosman, R.L., and Weiss, J.S., 1991, Geohydrologic units of the Mississippi embayment and Texas coastal uplands aquifer systems, south-central United States: U.S. Geological Survey Professional Paper 1416-B, 19 p.

Hutson, S.S., Barber, N.L., Kenny, J.F., Linsey, K.S. Lumia, D.S., and Maupin, M.A., 2004, Estimated use of water in the United States in 2000: U.S. Geological Survey Circular 1268, $46 \mathrm{p}$.

Mehl, S.W., and Hill, M.C., 2005, MODFLOW-2005, the U.S. Geological Survey modular ground-water model-Documentation of shared node Local Grid Refinement (LGR) and the Boundary Flow and Head (BFH) Package: U.S. Geological Survey Techniques and Methods 6-A12, 68 p.

Mehl, S.W., and Hill, M.C., 2007, MODFLOW-2005, the U.S. Geological Survey modular ground-water modelDocumentation of the multiple-refined-areas capability of Local Grid Refinement (LGR) and the Boundary Flow and Head (BFH) Package: U.S. Geological Survey Techniques and Methods 6-A21, 13 p.

National Oceanic and Atmospheric Administration, 2002, Divisional normals and standard deviations of temperature, precipitation, and heating and cooling degree days 1971-2000 (and previous normals periods): National Oceanic and Atmospheric Administration Climatography of the United States no. 85.

Parks, W.S., and Carmichael, J.K., 1989, Geology and groundwater resources of the Fort Pillow Sand in Western Tennessee: U.S. Geological Survey Water-Resources Investigations Report 89-4120, 20 p.

Parks, W.S., and Carmichael, J.K., 1990, Geology and groundwater resources of the Memphis Sand in Western Tennessee: U.S. Geological Survey Water-Resources Investigations Report 88-4182, 30 p.

University of Tennessee, Center for Business and Economic Research, 2003, Population projections for the State of Tennessee 2005 to 2025: University of Tennessee, 66 p., accessed April 29, 2008, at http:/www.state.tn.us/tacir/ population.htm.

Webers, Ank, 2003, Public water-supply systems and associated water use in Tennessee, 2000: U.S. Geological Survey Water-Resources Investigations Report 03-4264, 90 p. 
Prepared by:
USGS Publishing Network

Raleigh Publishing Service Center

3916 Sunset Ridge Road

Raleigh, NC 27607

For additional information regarding this

publication, contact:

USGS Tennessee Water Science Center

640 Grassmere Park, Suite 100

Nashville, TN 37211

(615) 837-4700

Or visit the USGS Tennessee Water Science

Center Web site at:

http://tn.water.usgs.gov 
